\title{
George Hunsinger, Ed. Karl Barth: Post-Holocaust Theologian?
}

\author{
(London: Bloomsbury T\&T Clark, 2018), xi + 171 pp.
}

\author{
DAVID NOVAK \\ david.novak@utoronto.ca \\ University of Toronto, Toronto, ON M5S, Canada
}

Since his death in 1968, the great Swiss-Protestant theologian Karl Barth has probably been the subject of more books and articles than any other contemporary religious thinker. This fact attests to Barth's great and well-deserved influence on thinkers who include not just his fellow Protestants but many others, including nonChristians.

In my own case, as a Jewish student studying to become a rabbi, I first heard Barth's teachings from his eldest son Markus, who was my teacher of New Testament at the University of Chicago in the early 1960's. (I was also privileged to briefly meet the great man himself when he spoke at Princeton University in 1962.) I mention this because I first learned of Barth's respect for Judaism when his son and chief disciple once scolded me for quoting Aristotle in a term paper when, as he put it, "you should have quoted the Talmud!" Thus, whenever I read Barth's magnum opus, Church Dogmatics, I discover (especially in the sections in fine print, where his exegetical skills are most visible) that his interpretations of the Hebrew Bible not only sound rabbinical but even have parallels in the Talmud and other rabbinical writings. That is because both Barth and the Rabbis were most carefully reading Scripture as the Word of God, which is Scripture's message speaking to the present situation of those hearing it as such. Lutheran theologian George Lindbeck, who was influenced by both Barth and Wittgenstein (especially his philosophy of language), once said that Christianity and Judaism have the same vocabulary but different conceptualities. That same vocabulary is scriptural. (Interestingly, the great Jewish theologian Joseph Soloveitchik had it precisely backward when he argued that Jews and Christians speak totally different languages.)

Barth not only respected Judaism but was a defender of living Jews. He opposed Nazism in both word and deed, seeing it above all as an assault on Jesus' Jewish brethren and hence on Christ himself. Both his respect for Judaism and his defense of Jews were thoroughly grounded in his theology. While some statements 
in his Church Dogmatics seem anti-Jewish, his rhetoric nevertheless often resembles a type of critical exchange among those basically speaking the same communal language. (A parallel can be found in New Testament accounts-especially in the Gospel of Matthew — of Jesus's debates with the Pharisees; neither side capitulates to the other nor resorts to the insults like those used by Jesus against the Sadducees and the Zealots.)

This book contains nine essays. Some are focused on the Holocaust and postHolocaust theology, while others are broader, covering related topics such as religious pluralism and the Second Vatican Council. In several of the essays the authors argue that Barth did not consider Judaism to be another religion, totally apart from Christianity, like Islam or Hinduism. In "Karl Barth's Influence on Catholic Theology about Judaism," Philip Rosato successfully demonstrates that Barth was quite critical of Nostra Aetate, which characterized Judaism as "another religion." For Barth, their interrelationship is much more complicated. The issue of the relationship between the two religions is raised by the editor George Hunsinger, a Reformed theologian, in his preface. He says that he believes "what David Novak has described as 'soft supersessionism' is required by the inner logic of the Christian faith" (p. ix). That is, "the old covenant is not replaced by the new, but it is fulfilled, extended, and supplemented, while also fundamentally confirmed in Christ." This position he attributes to Barth.

Hunsinger's statement presents an issue common to all the essays in this volume. The authors argue against the Scylla of a portrayal of Barth as a modern-day Marcionite, repudiating the Jewishness of Jesus and his Church. This type of repudiation led Christians to accept or ignore the kind of virulent antisemitism that led to the Holocaust. Simultaneously, all of them mutatis mutandis avoid the Charybdis of presenting a philosemitic Barth.

Barth has been criticized for his views on Jews and Judaism. The Jewish historian Daniel Jonah Goldhagen, in his popular 1996 book Hitler's Willing Executioners, strongly indicts him. He characterizes Barth as "a bitter opponent of Nazism ... despite his own deep-seated anti-Semitism" (quoted on p. 15). In his introduction to "Karl Barth's Sermon for Advent 2, 1933" (reprinted in chapter 2), John Michael Owen persuasively shows that Goldhagen's judgment of Barth is simplistic. Goldhagen did not give "a coherent and fair picture of Barth's attitude and actions with regard to the Jews of Germany between 1933 and 1945" (p. 16). The rest of the essays in this volume variously attempt to defend Barth from claims like those of Goldhagen, though not to the point of hagiography. They all address themselves to two main questions. One, was Barth an antisemite? Two, did Barth denigrate Judaism in order to elevate Christianity? Thus all the essays deal in some way with the relation of anti-Judaism and (racial and secular) antisemitism.

On the one hand, it seems impossible for antisemites not to be opposed to $\mathrm{Ju}$ daism as well. It is this religious tradition, passed on by their Jewish ancestors, that gives living Jews this hated identity. On the other hand, anti-Judaism does not necessarily lead to antisemitism. Christian supersessionists are anti-Jewish, viewing non-Christian Jews as seriously in error, and often even as opponents of Christianity. It is the task of Christians, believing that "superior" Christianity now supplants 
"inferior" Judaism in the divine economy, to show the Jews their error through proselytism. Usually, that kind of proselytizing is fiercely opposed to antisemitism (and rejected by antisemites as presumably too favorable to the Jews). However, and what is crucial to note here, is that Barth was opposed to proselytizing Jews because it seemed to him to be a form of Christian triumphalism at the expense of the Jews. For Barth, neither Christians nor Jews should be triumphalist at the expense of the other. The theological error of this kind of triumphalism is that it denies both Christian and Jewish sinfulness before God, thereby rejecting the salvation that can come only from God and not from human self-righteousness. Therefore, Barth was neither antisemitic nor even anti-Jewish, as a number of the essays show, with much deep thinking and wide erudition (especially, but not exclusively, the essay of Derek Woodard-Lehman, “Saying 'Yes' to Israel's 'No': Barth's Dialectic Supersessionism and the Witness of Carnal Israel").

Owen argues that Goldhagen and others seem to have misjudged Barth as antisemitic or anti-Jewish or both, based partly on Barth's own admission that he had an "aversion" or "allergy" to Jews (though he also admitted it was "totally irrational" and a source of shame) (p. 15-16). This mistaken impression might derive from an uncritical reading of his most extended treatment of Judaism and the Jews in his Church Dogmatics (especially II:2), which was written in the early 1940s. Further, while there is no doubt Barth should have been more sensitive to what was happening to the Jews in Europe, his actions speak louder than his words. Accusations like Goldhagen's are belied by the fact that while writing this volume, as Eberhard Busch has shown so well, Barth, at considerable risk to his own life, was helping Jews escape from the Nazis. (This was confirmed to me personally many years ago by Swiss-Jewish philosopher Jacob Taubes, who described himself as "Barth's only Jewish student.") Barth's clandestine acts during World War II are consistent with his heroic public pro-Jewish acts before and afterward the war.

This slim but rich volume demonstrates that Barth's life and work remain relevant, especially for the complicated Jewish-Christian relationship. It reflects Barth's hope that this unique relationship will endure until the coming of the Kingdom of God, or, in Jewish liturgical terms, until the time when all humanity will become "one bond" (agudah a $\underline{\text { hat }}$ ). 